\title{
Wayne Sandholtz and Christopher A. Whytock (Eds.), Research Handbooks on the Politics of International Law
}

\author{
(Cheltenham UK/Northampton USA Edgar Elgar, 2017) pp. 608, ISBN: 9781783473977
}

\section{Reviewed by Elspeth Guild \\ Queen Mary University of London}

A new contribution to the literature on international relations, politics and international law appeared in 2017, edited by Wayne Sandholtz and Christopher Whytock. Sandholtz, a specialist in international relations joins forces with a younger colleague, Whytock, a professor of international law, both established at US universities (in California) and with US based careers. Of the twenty two contributors to the book, fifteen are based at US universities, six at universities in Europe and one in Australia. There is a slight predominance of law professors, although international relations and politics specialists have a fair representation. It joins a number of other books on the subject which cover much of the same ground, such as Martti Koskenniemi's The Politics of International Law, ${ }^{1}$ and Christian Reus-Smit's edited volume The Politics of International Law Vol. 96. ${ }^{2}$ Koskenniemi's book is a monograph and an outstanding contribution to the field which builds on his analysis of what he terms the flight from politics (into law) in the historical setting of modern state system. This is very far from the proposition of the Sandholtz/Whytock edited volume, whose contribution more closely resembles the edited volume of Reus-Smit but with no overlap of contributors. Reus-Smit chose scholars with reputations for critical analysis who examine how international politics and law should be conceptualised in order to understand their relationship with a focus on events after 2001.

The Sandholtz/Whytock volume is organized around the premise that the relationship of law and politics in international law varies depending on where the relationship unfolds. In other words, as far as one can tell from the contents, tensions between law and politics are revealed in specific areas where international law impinges on national politics. This appears to be a more modest approach to the subject, in which realist perspectives dominate. Yet, it has an implicit framework, which is about power; this is substantially bolder and underpins the book without being formally acknowledged by contributors. As stated in the introduction, "power will be the central variable in the analysis of international law processes" ( $p$ 9). Yet, without an interrogation of what the editors mean by power, let alone how this differs depending on the contributor, the result is heterogeneous. The contributors do engage with the editors' interest in the unfolding of the relationship of law

\begin{tabular}{ll}
\hline 1 & Bloomsbury Publishing, 2011 \\
2 & Cambridge University Press, 2004
\end{tabular} 
and politics as one which takes place in specific sites. But from the international law perspective this is perhaps a little underwhelming - no one would claim that international law is similarly developed in the field of criminal law and in respect of nuclear non-proliferation. The contributors, however, do not seem to share the editors understanding of power or how it works either in politics (national or international) or in law (national or international).

The book is divided into two sections: (1) law, politics and institutions; and (2) sites of governance. The chapters within each cover a wide range of issues not always clearly falling within the scope of the section in which they are found, but some chapters are interesting with substantially useful insights for academics who are already very familiar with the issues of law and politics.

In the first section, the editors have chosen seven chapters which all revolve around the reception of international law in national politics. The first, by Hillebrecht, examines the issue of compliance within international law - whose job is this, what does it mean, how does it happen and who measures it. The next chapter, by Brewster, looks at effectiveness, basically following the same typology as the first chapter but perhaps with a more nuanced approach which acknowledges the interconnection of law and politics whether national or international. The third chapter provides an overview of international law in domestic courts (by Sloss and Van Alstine). Once again the chapter concludes that the reception of international law in domestic courts depends on the subject matter and whether the international rule in question is a horizontal, transnational or vertical one (all of which are defined and considered in the chapter). Following this chapter is one by Cope on treaty law and national legislative politics where the argument broadly underlying the book as a whole is more clearly delineated: national politics (and legislatures) create, interpret and apply (or not) international law - end of story. This is a very different approach to the one which emerges from the other two books which carry the same title, where international law is examined from the perspective of the authority which it acquires in its various manifestations.

It is not surprising then that the $6^{\text {th }}$ chapter (Verdier and Versteeg) looks at the ways in which international law may or may not be incorporated into national law and politics. Next is a chapter by Fraude and Gehring investigating international overlap in international law, a consequence of different regimes for different subject matters. This ends Part I on a note regarding the importance of inter-institutional coordination in international law - a consequence of its fragmentary nature (and dependence on national politics).

In Part 2, the objective is to examine the book's thesis from different sites of governance which engage international law. This approach lends some coherence to the book but the choice of subject matters is rather diverse.

Mattli and Seddon examine global financial and environmental standards, two subjects about which they are particularly well equipped. This chapter is very interesting and well written, but from the perspective of the coherence of the book the reader has to wonder why these two subjects have been merged together; each is a distinct and important site of international law governance (and the second will be the subject of its own chapter at the end).

Madsen wrote the following chapter on a subject about which he too is very expert - the European Court of Human Rights and the politics of international law. Once again this is a very good chapter but one which sits uneasily in the book - no 
other regional court is examined in the book although there are many. One might have expected a chapter which analysed the role of regional courts in general in the politics of international law rather than merely one European court.

Chapter 10 on the WTO dispute settlement mechanisms by Shaffer, Elsig and Puig is interesting and informative about the system, but its integration into the structure of the book seems somewhat superficial. Intellectual property is the subject of the next chapter by Sell, once again interesting, very pertinent to the development of international law but the conclusions which follow from the analysis, although couched in terms of the objective's project, seem strained.

Susan Katzenstein wrote the next chapter on non-state actors and human rights in legalization and transnational regulation. Again this is an interesting chapter by an expert who has examined the area. The addition of the private sector as an actor is an interesting dimension which does not appear again.

Chapter 13 takes as its subject the 'war' on terror and international law, written by Paust and very heavily footnoted. It provides a clear and orthodox legal analysis of various acts (primarily carried out by the USA) from the perspective of their compatibility with international law. As such, this chapter demonstrates perhaps the antithesis of the editors' project as the assumption of the chapter is the overarching authority of international law and the entitlement of its practitioners (such as Paust) to condemn state practices which are inconsistent with it (with no nod to the suggested primacy of national politics).

The next two chapters, on cyber conflict (Banks), and the internet (Chander), deal with very recent issues and preoccupations. Both chapters outline the development of international law - the application of existing rules in the cyber conflict chapter and the search for international consensus on a high dynamic amalgam of practices in the internet. Both assume not only the existence of international law but also its authority notwithstanding national politics as a beneficial force.

The final chapter comes back to the subject of environmental law by Peterson which is a little surprising as the subject was already dealt with as a site of international law's confrontation with national politics by Mattli and Seddon. The consistency of the description of the state of international environmental law is quite different in the two chapters.

The conclusion, that continuing controversy should be expected in the area, as there are winners and losers with each development, is a little underwhelming. There is no concluding chapter to this book which might have attempted to bring together some of the subjects in light of the objective set out at the start.

This book has its merits and there are a number of very interesting chapters which are both highly informative about developments in international law in specific areas, and provide some useful analysis about those developments. However, as a whole, the book is somewhat disappointing. First, the editors set out their project for the book in a manner which is neither clear nor coherent. The lack of any attempt to provide a definition of power to back up their inherent claims, that power is a characteristic of national politics and exercised through violence, is missing. This deficit is problematic not least as it does not appear to be shared by many of the authors. From another standpoint, the distribution of the contributing authors between the USA in the first instance and Europe in the second (and well behind) raises the question of whether the issue of international law and national politics is one which is geographically situated somewhere in the Mid Atlantic but closer 
to the US coast. While a number of authors refer to judgments of courts in a wide range of jurisdictions, the perspective is one geographically situated elsewhere (USA and Europe). I would recommend some of the chapters of this book for advanced students - with a proviso that perhaps the most useful parts are the descriptions of the state of the art in various areas of international law and that the state of art is a fairly rapidly moving target and likely to be out of date quickly. 